\title{
Effect of using Problem-Based Learning on the Academic Achievement of Higher Secondary School Students
}

\author{
Tshewang Dorji \\ Ohttps://orcid.org/0000-0002-9022-2314 \\ Dechencholing Higher Secondary School, Thimphu Thromde, Bhutan \\ Ministry of Education \\ *e-mail: tshewangtshewang@gmail.com
}

\section{Article Information \\ Received: December 28, 2020 \\ Revised: January 17, 2021 \\ Accepted: January 21, 2021 \\ Online: May 30, 2021}

\begin{tabular}{l}
\hline \multicolumn{1}{c}{ Keywords } \\
\hline Problem-based learning, teaching \\
strategy, experimental group, the \\
control group
\end{tabular}

\begin{abstract}
The Quasi-experimental study examines the effect of the Problem-based Learning (PBL) teaching strategy on the academic achievement of one higher secondary school student under Thimphu Thromde, Bhutan. The student participants were selected through non-probability convenient sampling techniques. All students of XI Arts $(N=30)$ and XI Commerce $(N=38)$ participated in the study. Class XI Arts students were used as a controlled group and XI Commerce students as an experimental group. The experimental group was taught using $P B L$, and the control group was taught using the traditional lecture method. The pre-test data were collected through class test 1, and post-test data were collected through class test 2 and 5 points Likert scale survey questionnaire. The results revealed that the experimental group scored higher marks in the class test than the control group. The XI Arts and XI Commerce (both controlled groups) were 40.75 and 38.81 initially. The mean score of the post-test of the experiment group showed 44.73, while the controlled group managed only 43.00. Further, the experimental group had a favorable opinion on the effectiveness of the PBL strategy. The study recommends the implementation of a PBL teaching strategy despite PBL being time-consuming and resource-intensive.
\end{abstract}

\section{INTRODUCTION}

The primary determinant of effective teaching-learning in the classroom is teachers' teaching strategy (Yadav, 2009). Teachers need to rely not on their past achievements or teaching strategies but practice innovative teaching strategies that promote constructive thinking. In the 21st century, teachers must make students confident, competent, and conscientious in a competitive future. If students are not adequately educated, a nation might face difficulty in attaining the national developmental goals and vision. Boris (2020, p.74) argues that a "teacher may profess to hold fifteen years' experience, but the experience means nothing if he keeps on repeating the same thing without bringing innovation into his teaching." The teaching-learning becomes effective if the curriculum is implemented correctly in the classroom with appropriate teaching strategies, instructional tools, and assessments. The teacher needs to practice strategies that motivate students and support the achievement of desired learning outcomes. According to the NCERT (n.d.), one of the main reasons for the poor performance of students in economics in higher secondary school is the lecture-based teaching strategy, which emphasizes more on giving information rather than learning. Lecture instruction does not promote cognitive learning skills, application abilities, and motivation to students; instead limits the scope for developing 
confidence, independence, and learning abilities. The Bhutan Professional Standards for Teachers (MoE, 2020) requires all teachers to adopt appropriate content and pedagogical practice to develop higherorder thinking skills in students. The quality of education has a determinantal impact on the nation's competency, well-being, and success. Economics discipline being primary bedrock for the transformation of the nation's economy and national development, scholars recommend PBL teaching strategy in economics disciplines to solve real-life problems (NCERT, n.d).

The origin of PBL is traced from medical and health care education in the United States since 1991, and teachers are using it in strategizing teaching in the classroom (NCERT, n.d.). According to Ai-Girl, Kumar, and Ho (2005), PBL is a specific teaching strategy to solve problems by bringing learning experiences as it uses real-life problems to initiate active learning. It makes learning relevant to teachers by narrowing the gap between knowledge acquisition and professional practice. Awodun (2015) defines the PBL strategy as a teaching strategy in which students use previously acquired knowledge and skills to satisfy unfamiliar situations or problems. PBL is considered the pinnacle of using problem-solving as a teaching strategy (Killen, 2009). PBL is consistent with the constructivism philosophy, that knowledge is not absolute, and students can construct knowledge based on their previous knowledge, experience, and worldview (Ai-Girl, Kumar \& Ho, 2005). PBL is known as a student-centered pedagogy (Killen, 2009).

Economics discipline creates an avenue for students to explore real-life issues and solutions (NCERT, n.d.). Moreover, students get to use economic theories to acquire solutions working in various organizations such as financial institutions, enterprises, government organizations, companies, etc. Therefore, PBL as an effective teaching strategy can emulate problem-based situations, enhancing the knowledge retention power of students. Under PBL, the teacher's goal is not to teach but to facilitate and guide students to identify issues and objectivities from problems. Therefore, before any learning occurs in PBL, the teacher should first introduce students to real-life problems of the designated area (Barrows, 1985). Then, the teacher develops inquiry skills to overcome the problem posed in real life by encouraging students to search for facts and solutions themselves. However, to have successful completion of PBL in the classroom, the teacher should possess sufficient economics knowledge and have the ability to manage students to developed focused inquiry (NCERT, n.d.).

According to NCERT (n.d.), there are several advantages of using PBL: (i) PBL facilitates and promotes peer-group discussions and helps students to learn to make decisions; (ii) PBL promotes selflearning to achieve concept attainment; (iii) where more than one answer or solution are expected under such circumstances, PBL is suitable for creative tasks; (iv) students to come together to solve problems collectively with different views and ideas; (v) students learn to search for information through various sources; (vi) PBL brings more significant and better opportunities for teacher-student and student-student interactions; (vii) PBL promotes confidence and independence learning skills; (viii) PBL develops and promotes a sense of responsibility to contribute as a team effort; (ix) PBL assigns students to find the time, manage time, use time effectively inside and outside the school to maximize the utility.

Liu (2004) found that average and gifted students perform well in assessments under the PBL teaching strategy. Students score higher-grade when PBL is applied in the classroom (Seger, Bossche \& Teunissen, 2003). Students who were taught using PBL enjoyed more learning and gave higher evaluations to their curriculum than non-PBL students (Morrison, 2004). The probable causes were data gathering, problem-solving, self-assessment technique, and learning competency. PBL students had higher satisfaction and accomplishment with a limited adverse effect on academic grades (Nalesnik, Heaton, Olsen, Haffner, \& Zahn, 2003). Learning becomes more meaningful under PBL, where students can apply experience to a real-life situation (Carder, Willingham \& Bibb, 2001). Learning through PBL was described as attractive, fun, and realistic, enabling problem-solving to overcome the theory-practice gap (Bechtel, Davidhizar \& Bradshaw, 1999; Cooke \& Moyle, 2002). PBL challenges students to perform with critical reasoning and problem-solving skills to draws its conclusion (Barrows, 1985; Cooke \& Moyle, 2002). Carey \& Whittaker (2002); Sharp \& Primorse (2003) found that many students had a positive attitude toward PBL application and enjoyed the teaching-learning process.

There are six strategies to create a PBL environment in economics classrooms. However, according to NCERT (n.d.), most teachers prefer these six steps to create a PBL environment in the classroom: 
1. Determine the PBL environment; The teacher should decide whether the entire or partial topic can be taught, and the decision taken by teachers depends on the ability and enthusiasm of students, the nature of the subject, and the availability of resources.

2. Focus on learning outcomes; It includes statistical tools - tables, graphs, data analysis, and transferable skills such as time management, independent learning, teamwork, decision making, problem-solving and communicating skills.

3. Determine the learning activities; Learning activities need to be associated with the task that enhances subject-specific skills and transferable skills.

4. The teacher will present the task and activities to students

5. The teacher set up proper mechanisms to facilitate students to lead, record, and monitor individual or groups

6. In the end, the teacher needs to assess the tasks or assignments.

Similarly, Bouhuijs and Gijselaers (1993) and other scholars suggested the following steps to create a PBL environment in the classroom:

1. Small group; Organize students into small groups of 6-8 members, and each group will work independently from other groups so that all students can participate in problem analysis. Small groups facilitate students to acquire knowledge, communication, problem-solving, teamwork, team spirit, sharing information, respect for others, and promoting independent learning.

2. Identify problems from the lesson; The teacher assigned an ill-structured, complex, realistic, and open-ended set of problems related to the lesson to foster flexible thinking.

3. First meeting; Discuss the problem for the first time to acquire the first impression or opinions of the problem.

4. Brainstorming; Brainstorming sessions for the groups to identify issues and essential information required to solve the problems.

5. Task or activities; Identify specific study tasks such as library research before meeting in the next class. While designing a study task teacher needs to:

a. be aware of the learning activities and be consistent with the learning objectives or outcomes specified in the lesson.

b. Examine the difficulties or challenges that students might arise in the process, including computer facilities, library resources, access to the internet, newspapers, research articles, textbooks, and other materials.

c. Teachers will allocate tasks to individual group members.

d. Ask all groups to select a group 'leader' and group 'recorder' responsible for leading the group ensuring all members participate in team discussions. The teacher will not interfere with the governance of group procedures.

e. During any subsequent meetings, group members are expected to undertake the task allocated to the group. For example, the tasks might include (i) providing a summary and assessment of relevant magazines, journal articles, and newspaper clippings. (ii) Searching or browsing materials through the internet (iii) obtaining and tabulating relevant statistical information.

f. The teacher will give sufficient time to facilitate research and ensure that all students participate actively in the discussion and provide constructive critique as and when required.

g. Teachers should scaffold students learning through guiding and coaching with a questioning strategy.

h. Finally, the teacher needs to ask for a formal presentation in the class or a written report and provide formative feedback to each group. If needed, the teacher can convert formative assessment into summative assessment or grade it into a continuous summative assessment.

\section{Significance of the Study}

Research-driven classroom practices are essential in making pedagogical practices relevant. Many scholars recommend teachers to be researchers for reflective practice and investigation skill development (MoE, 2019). The study will be helpful for the teachers in doing informed pedagogical practices to enhance students' academic performance. 


\section{The objective of the study}

There is no definite study carried out in Bhutan to assess teaching strategy, and the study aimed to examine students' academic achievement using the PBL teaching strategy against the traditional lecture method.

\section{Research Question} method?

1. Do students taught using the PBL strategy score higher marks than the traditional lecturer

\section{METHODS}

The study adopts Quasi-experimental with pre-test and post-tests. The pre-test was done before implementing the intervention program to determine the student's academic ability. The Post-test was carried out after the intervention program to determine the effect it on the disciplines. Pre-test and posttest used the same instrument (class test 1 and class test 2 each with 20 marks). After post-test, the researcher also administered 5 points Likert scale survey questionnaire ( $5=$ Strongly Agree, 4= Agree, $3=$ Neutral, $2=$ Strongly Disagree, $1=$ Disagree) to examine the student's opinion experimental group towards the intervention program. The researcher randomly selected the experiment and controlled the group through the 'lucky dip' method. The researcher taught a module-poverty using PBL teaching strategy for the experiment group (XI Commerce), while the control group (XI Arts) was taught the same module using the traditional lecture method.

\section{Population and sample}

This study consisted of all class XI (Arts and Commerce) students of one higher secondary school under Thimphu Thromde, Bhutan. There were 30 students (19 girls and 11 boys) in XI Arts and 38 students ( 23 girls and 15 boys) in XI Commerce. Of the 38 students, 24 students ( 12 girls and 12 boys) in XI Arts had not taken economics in class IX and X. Similarly, out of 38 students, 23 students (17 girls and six boys) in XI Commerce had not taken economics in class IX and X. They were studying economics for the first time in class XI.

\section{The instrument for data collection}

\section{Pre-test}

The pre-test (class test 1) with a writing time of 45 minutes was conducted on April 24, 2019, as per the school academic policy. Six short questions were prepared from Unit 1 from the class XI economics syllabus with 20 marks. The 20 marks were later converted into 100 marks for more straightforward tabulation. The class test 1 response was graded and later convert to $2 \%$ for continuous internal assessment. The pre-test was conducted for the control and experimental group. After the pretest (class test 1), the experimental group (XI Commerce) was taught using PBL, while the traditional lecture method was used for the control group (XI Arts). XI Arts scored better during class test 1

\section{Post-test}

The post-test was conducted for both the controlled and experimental groups with identical paper. The pre-and post-test scores were compared to see the academic performance of the group before and after the implementation of the intervention program.

\section{Survey Questionnaire}

After the post-test, a 5-point Likert scale survey questionnaire (5= Strongly Agree, $4=$ Agree, $3=$ Neutral, 2= Strongly Disagree, 1= Disagree) was administered to determine students' opinions intervention program.

\section{Intervention program}

After the pre-test, the researcher identified possible topics that students could explore. Then, PBL intervention was given to the experimental group (XI Commerce) students for three weeks. As students were new to the PBL, the researcher briefed essential skills such as collaboration, interpersonal relationships, time management, and respect for ideas and research crucial. Next, the lesson was shared 
with the experiment group on the module poverty. Finally, the researcher formulated a few questions to form problems.

1. How is poverty defined?

2. How can we differentiate absolute poverty, relative poverty, subjective poverty, and poverty line? (c) o you think the way official documents identify a person affected by poverty is appropriate?

3. Examine the changes in the magnitude of poverty in Bhutan since 1960.

4. Do you think only the government has the responsibility to address poverty?

5 . What are the steps we may have to take to alleviate poverty?

6. How can we, as responsible citizens can reduce poverty?

7. As a student, how will you overcome poverty?

The PBL was implemented after students have acquired basic knowledge of the subject and after teaching appropriate problem-solving strategies. The researcher made sure that the students have reached the level of intellectual maturity to reap the benefit of PBL. XI Commerce students were divided into six groups on a lucky dip basis consisting of 6 members in the first four groups and seven members in the last two groups. Each group was assigned the following questions:

\section{Group 1}

1. Although poverty has been dramatically reduced in many parts of the world, countries such as Latin America, Africa, and South Asia are still characterized by acute poverty. How is poverty defined?

2. To better understand poverty and its solution, it is essential to have clear-cut information on the concept of poverty. Poverty is multidimensional. How can we differentiate 'absolute poverty, relative poverty, 'subjective poverty,' and 'poverty line'?

\section{Group 2}

1. Do you think the way official documents identify a person affected by poverty is appropriate? Use real-life examples to argue the case.

2. Despite economic growth, massive poverty continues to exist in the country. How would you explain this phenomenon?

\section{Group 3}

1. Examine the changes in the magnitude of poverty in Bhutan since 1960.

2. What would happen to the government and the nation if there were no poverty across the country? Justify with five reasons.

\section{Group 4}

1. Do you think only the government has the responsibility to address poverty? Justify with five reasons.

2. Poverty is the cause of all evils in society. Explain with five reasons.

\section{Group 5}

1. What are the steps we may have to take to alleviate poverty in Bhutan?

2. Do you agree that measures taken by the government of Bhutan to control poverty are inadequate? If so, give other measures to control poverty.

\section{Group 6}

1. Poverty is a great curse. It needs to be removed not only on ethical and humanitarian considerations but also on economic grounds. How we, as responsible citizens can reduce poverty in Bhutan?

2. As a student, how will you overcome poverty in your small way?

To facilitate learning through exploration, the students were asked to explore all available information technology. The researcher informed students on the kind of books, magazines, journals, and resources needed on poverty to find the solutions for the problems. Groups started collecting information through multiple means (i.e., library, internet, etc.) and discussed the adequacy of materials to leap toward solutions to the problems posed by the researcher. Group recorders read and summarize the possible solutions. During the review, the researcher shared additional crucial points, if necessary, 
to supplement the solution proposed by the group. Finally, the groups, having incorporated the changes highlighted by the researcher, presented their findings in charts and PowerPoint slides.

\section{The validity of the instrument}

The pre-test, post-test, and 5 points Likert survey questionnaire was validated through peer review from teaching faculty to override biased interpretations.

\section{Data Analysis}

The pre-test and post-test data collected through class tests were analyzed using SPSS version 24. In addition, the data collected from the 5-point Likert scale survey questionnaire were analyzed using mean and standard deviation scores to determine the opinion towards the PBL intervention program.

\section{RESULTS \& DISCUSSION}

There was no significant difference in class test mean scores in the control and experiment groups before the intervention program, as shown in Table 1.

Table 1. Comparison of class test 1 and class test 2 between the controlled and experimental group

\begin{tabular}{llccc}
\hline Group & Class Test & Mean & $\begin{array}{c}\text { Standard } \\
\text { Deviation }\end{array}$ & Remarks \\
\hline Pre-test & Control [XI Arts] & 40.75 & 9.17 & No Sig. \\
& Control [XI Commerce] & 38.81 & 12.50 & Sig. \\
Post-test & Control [XI Arts] & 43.00 & 7.52 & 11.04 \\
& Experiment [XI Commerce] & 44.73 & & \\
\hline
\end{tabular}

The mean score of the pre-test (class test 1) of the XI Arts and XI Commerce (both controlled groups) were 40.75 and 38.81. The mean score of the post-test (class test 2) of the XI Arts (controlled group) and XI Commerce (experiment group) were 43.00 and 44.73. Table 1 shows a slight increase in the test score of the experiment group (XI Commerce). There is a statistically significant rise in test scores in the post-test in comparison to the pre-test. The experimental group benefitted more than the control group due to the intervention program. The result is further supported by analysis of the 5 points Likert survey questionnaire as shown in Table 2.

Table 2. Descriptive Statistics

\begin{tabular}{clccc}
\hline Sl No. & \multicolumn{1}{c}{ Items } & N & Mean & SD \\
\hline 1 & The teacher engaged me actively and meaningfully & 38 & 4.6053 & .63839 \\
2 & PBL provide greater interaction between teacher-student and & 38 & 4.3158 & .61973 \\
& student-student & & & \\
3 & PBL develop confidence and independent learning skills & 38 & 4.6579 & .58246 \\
4 & PBL makes learning interesting, enjoyable, and fun & 38 & 4.5789 & .64228 \\
5 & I learn better with PBL & 38 & 4.1316 & .84377 \\
6 & PBL makes the concept, hypothesis, problems easier & 38 & 4.0789 & .67310 \\
7 & PBL promotes cooperation, team spirit, respect for peers & 38 & 4.3947 & .94553 \\
8 & PBL helps us in developing essential skills such as decision & 38 & 4.3684 & .85174 \\
& making, problem-solving communication, and negotiation & & & \\
9 & PBL enhance motivation to learn economics in the classroom & 38 & 4.4737 & .68721 \\
10 & I score good marks in economics through PBL & 38 & 3.8158 & .76601 \\
11 & My academic performance improved after using PBL & 38 & 3.9211 & .74911 \\
12 & I recommend PBL to teach economics in higher classes & 38 & 4.2105 & .84335 \\
\hline & Total Mean & 38 & 4.2960 & \\
\hline
\end{tabular}


The total mean score of the survey questionnaire was 4.2960, as shown in Table 2. Thus, the experimental group showed a favorable opinion toward PBL teaching-learning and, therefore, validates its remarkable impact on learning. Furthermore, the results and discussion agree with the literature review of NCERT (n.d); Carey and Whittaker (2002); Sharp and Primorse (2003); Morrison (2004).

\section{Reflection of the study}

According to Race (2010, p.238), "Good teacher reflect all the time, both during teaching and afterward." No matter how well a teacher teaches, there is always room for negotiation and improvement. Multiple challenges are being confronted during the study. However, the literature review helped the researcher to navigate BPL implementation and understand its implication on teaching-learning. While PBL is an effective strategy compared to the traditional lecture method, it consumes time and resources to support and enrich student learning.

Researcher notices during class evaluation that students preferred to work out a solution through the traditional lecture method due to limited time, limited accessibility of resources \& information, and minimal support from the teacher to complete the task. The limited experience of the researcher on PBL strategy impacted in maintaining the standard of work and efficiently facilitating the group during the session. The facilitator is key to student success in PBL strategy as he/she would be responsible for moving students through various stages of PBL to monitor the progress. An average teacher in Bhutan might find it challenging to implement PBL due to limited time, expertise, and vast syllabus. Moreover, Bhutanese education is examination-oriented, while PBL requires more formative assessment. The researcher found that there were insufficient resources available in the school to support the self-direct teaching-learning. The Internet facility, computer, and library resources are inadequate, and students have limited access. According to Baker (2000), there should be sufficient resources and educational support for self-direct learning.

The researcher found that 70 percent of students could not apply economic theories and concepts in the classroom as students were pursuing economics for the first time in class XI. Students copying directly from the textbooks and the internet were some of the difficulties the researcher confronted. The teacher needs to carefully observe all activities and take time to go through all the written reports to discourage students from copying directly from other sources. Bhutanese students lacked the skills of academic writing. PBL is time-consuming, requiring efforts from students as well as the teacher. PBL in the classroom is demanding and requires more time for planning, resource availability, and expertise, typically in large class sizes. In the current Bhutanese classrooms, the class size is 35 to 40 students, limiting the scope of implementing PBL effectively. Despite the challenges, it should be an endeavor to implement the PBL teaching strategy in their classroom to harness the immense benefit offered by the model in teaching-learning. Through PBL, the researcher gained a deeper understanding of supporting students to solve problems and introspect on the experiences. Through constant interaction between the students and teacher with PBL strategy, it could uplift the self-esteem of students and transfer ownership of learning to students themselves

\section{Limitation of the Study}

The limitation of the study was the duration of the intervention program. The study could be more valid and reliable if the duration of the intervention program were longer. Due to limited time and resources, teachers and school management views could not be collected, which otherwise would have value-added significantly to the study. The future researcher can replicate the same study in their respective school with a more extended intervention period, and a larger sample size draws the comparison.

\section{CONCLUSION}

The study examines the effect of PBL on academic performance in higher secondary schools under Thimphu Thromde, Bhutan. The mean score of the pre-test (class test 1) of the XI Arts and XI Commerce (both controlled groups) were 40.75 and 38.81. The mean score of the post-test (class test 2) of the XI Arts (controlled group) and XI Commerce (experiment group) were 43.00 and 44.73. The study concluded that the PBL model is a more effective teaching strategy than the traditional lecture method. 
Students taught using PBL performed better than the traditional lecture method. PBL teaching strategy showed the potential to improve the academic performance of students and school at large despite being time-consuming and resource-intensive. PBL being student-centered, the Ministry of Education's effort to transit from erstwhile traditional teaching has driven brighter hopes for the future. However, it is essential to adequately transfer requisite knowledge to teachers and create facilities in schools.

\section{Funding and Conflicts of Interest:}

The authors declare that there is no funding and conflicts of interest for this research.

\section{REFERENCES}

Ai-Girl, T., Kumar, R.S., \& Ho, V. (2005). Project-based learning. In Tan. A., Cheah, H., \& Chong, S, Educational Innovation: A perspective on class size, team teaching, alternative pedagogies, and assessment (pp. 122-149). Jurong, Singapore: Prentice-Hall. Available at: https://www.pearson.com/us/higher-education.html

Awodun, A.O. (2015). Effects of Problem-Solving Teaching Strategy on Secondary School Students' Academic Achievement in Physics. European Modern Studies Journal, 4(3), 21-29. Retrieve from: http://ijrar.com/upload issue/ijrar issue 20544181.pdf

Baker, C.M. (2000). Problem-based learning for nursing: integrating lessons from other disciplines with nursing experiences. Journal of Professional Nursing, 16(5), 258-266. Retrieve from: https://pubmed.ncbi.nlm.nih.gov/11033935/

Barrows, H.S. (1985). How to design a problem-based curriculum for the preclinical year. New York, USA: Springer Publishing Company. Available at: https://www.amazon.com/Problem-BasedCurriculum-Preclinical-Springer-Education/dp/0826149006

Bechtel, G.A., Davidhizar, R., \& Bradshaw, M.J. (1999). Problem-based learning in a competency-based world. Nursing Education Today, 19, 182-187. Available at: https://pubmed.ncbi.nlm.nih.gov/10578827/

Boris, O. O. (2020). Effects of Problem Solving Teaching Strategy on Secondary School Students' Academic Performance in Chemistry in Ondo State, Nigeria. IJRAR-International Journal of Research and Analytical Reviews, 7(2), 74-80. Retrieve from: http://ijrar.com/upload issue/ijrar issue 20544181.pdf

Bouhuijs, P., \& Gijselaers, W. (1993). Problem-based learning as an Educational Strategy. New York, USA: New York Publications. Available at: https://link.springer.com/chapter/10.1007/97894-015-8545-3 5

Carey, L., \& Whittaker, K.A. (2002). Experiences of problem-based learning: issues for community specialist practitioner students. Nurse Education Today, 22, 661-668. Retrieve from: https://www.researchgate.net/publication/11024451 Experiences of problembased learning Issues for community specialist practitioner students

Carder, L., Willingham, P., \& Bibb, D. (2001). Cases-based, problem-based learning information literacy for the real world. Research Strategy, 18, 181-190. Retrieve from: https://www.researchgate.net/publication/223065617 Case-based problembased learning Information literacy for the real world

Cohen, L., Manion, L., Morrison, K., \& Wyse, D. (2010). A guide to teaching practice （5th ed.). Madison Avenue, New York: Routledge. Available at: https://www.routledge.com/A-Guide-toTeaching-Practice-5th-Edition/Cohen-Manion-Morrison-Wyse/p/book/9780415485586

Cooke, M., \& Moyle, K. (2002). Students' evaluation of problem-based learning. Nurse Education Today, 22, 330-339. Retrieve from: https://pubmed.ncbi.nlm.nih.gov/12030754/

Killen, R. (2009). Effective Teaching Strategy: Lesson from research and practice (5th ed.). Sydney, Australia: C\&C Offset Printing Co Ltd. Available at: 
https://www.scirp.org/(S(i43dyn45teexjx455qlt3d2q))/reference/ReferencesPapers.aspx?R eferenceID $=1412301$

Liu, M. (2004). Examining the performance and attitudes of sixth grades during their use of a problembased hypermedia learning environment. Computers in Human Behaviour, 20, 357-379. Retrieve from: https://www.researchgate.net/publication/222673678 Examining the performance and at titudes of sixth graders during their use of a problembased hypermedia learning environment

MoE. (2019). Action Research Seminar: Enhancing teaching and learning practice through reflection. Thimphu, Bhutan: MoE. Retrieve from: http://www.education.gov.bt/wpcontent/uploads/2020/07/Proceedings-of-the-First-Action-Research-with-cover.pdf

MoE. (2020). Bhutan Professional Standards for Teachers. Thimphu, Bhutan: MoE. Retrieve from: http://www.education.gov.bt/index.php/bhutan-professional-standards-for-teachersreleased/

Morrison, J. (2004). Where now for problem based learning? The lancet, 363-174. Retrieve from: https://pubmed.ncbi.nlm.nih.gov/14726191/

Nalesnik, S.W., Heaton, J.O., Olsen, C.H., Haffner, W.H.J., \& Zahn, C.M. (2003). Incorporating problembased learning into an obstetrics/gynecology clerkship: Impact on student satisfaction and grades. American Journal of Obstetrics and Gynecology, 190, 1375-1381. Retrieve from: https://pubmed.ncbi.nlm.nih.gov/15167844/

NCERT. (n.d.). Teaching Economics in India; A Teachers's Handbook. Delhi, India: NCERT. https://www.ncert.nic.in/dess/pdf/handbook in economics.pdf

Race, P. (2010). Making Learning Happen (2nd ed.). Singapore: SAGE Publications Asia-Pacific Pte Ltd. https://www.academia.edu/26374132/Making Learning Happen A Guide for PostCompulsory Education. By Phil Race. Thousand Oaks Calif. Sage Publications 2010. xi 250 pages. ISBN 978-1-84920-114-8. 44.95

Segers, M., Van den Bossche, P., \& Teunissen, E. (2003). Evaluating the effects of redesigning a problem-based learning environment. Studies in Educational Evaluation, 29, 315-334. Retrieve from: https://core.ac.uk/download/pdf/231259237.pdf

Sharp, D. M.M., \& Primrose, C.S. (2003). The "virtual family." An evaluation of an innovative approach using problem-based learning to integrate curriculum themes in a nursing undergraduate programme. Nurse Education Today, 23, 219-225. Retrieve from: https://journals.sagepub.com/doi/10.1177/1074840710366565

Yadav, A. (2009). Teaching of Economics. New Delhi, India: Anmol. Retrieve from: https://www.biblio.com/book/teaching-economics-amita-yadav/d/1336573546 